\title{
Angyal Diána
}

\section{Magad Uram! \\ Személyes kompetenciák fejlesztése self-coachinggal a közszolgálatban}

Jelen tanulmány azt vizsgálja, hogy a közszférában dolgozók miképp tudják fejleszteni személyes kompetenciáikat self-coaching eszközökkel. Az ön-coaching alkalmazásának hatására nö az önbizalom, az önértékelés, az egyén rugalmasabbá válik, fejlödik az önkontroll, mely személyes kompetenciákra különös figyelmet forditanak a közszférában.

Kulcsszavak: kompetencia, változás, hatékonyság, teljesitmény, coaching

JEL-kódok: O15, M12, M19, M53

https://doi.org/10.32976/stratfuz.2019.9

\section{Bevezetés}

A munka világában a változások gyorsan követik egymást, melyek az alkalmazottakkal szemben is egyre nagyobb elvárásokat támasztanak a munkakörnek való megfelelés tekintetében (Langer, 2001).

Aktuális kihívást jelent a digitalizáció és az e-kormányzás, valamint a gyors fejlődés. Egyre több munkakör változik a közszférában is, amely nem csak új feladatokat és felelősségi köröket eredményez, hanem a munkaadók elvárása is változik. Az újítások elfogadásához rendkívül fontosak a soft skillek, mint például az elfogadó hozzáállás, a tanulási készség és a változások hatékony kezelése.

\section{Néhány gondolat a kompetenciákról}

A kompetenciák egyéni, csoportos és szervezeti szinten is definiálhatóak. Az egyéni kompetenciák összessége, azok összefüggésrendszere befolyásolja a szervezeti hatékonyságot, a rugalmasságot és így a versenyképességet is (Varga, et al., 2017).

A kompetenciákat többféleképp definiálják, azonban azonosságok, átfedések bizonyos tekintetben fennállnak. A kompetencia valamilyen magatartással, viselkedéssel kapcsolatos tulajdonság-halmaz, amely szorosan kötödik a kiemelkedö teljesítmény eléréséhez nélkülözhetetlen jellemzökhöz.

A munkahelyi teljesítmény feladatorientált kompetenciák (hard) és érzelmi alapú (soft) kompetenciák kombinációjaként is jellemezhető. „Kemény”, azaz technikai kompetenciák azok a tevékenységek, amelyeket a munkavállalónak tudnia kell a megfelelő színvonalon elvégezni, tehát „amire alkalmas”, a „lágy” vagyis az érzelmi alapú kompetenciák pedig a kompetens teljesítményt lehetővé tevő viselkedésformákra utalnak, melyek például a kreativitás, érzékenység (Kenworthy, 2008).

Goleman (2004) évtizedekig foglalkozott azzal a kérdéssel, hogy milyen képességek illetve készségek kellenek a sikerhez. Három részre osztotta a sikert befolyásoló tényezőket: IQ (általános intelligencia), GYQ (gyakorlati intelligencia) és EQ (érzelmi intelligencia), valamint az ezekre épülö kompetenciák. Véleménye szerint az érzelmi kompetenciákban keresendő a fö különbség, amelyek közé sorolható például a lelkesedés, a kitartás, az önkontroll és az, hogy motiválni tudjuk saját magunkat. Úgy vélte, nincs kétség afelől, hogy egy jó munkahely megtalálásában jelentős szerepe van a kiváló iskolai végzettségnek, azonban a sikerhez már sokkal inkább van szükség a kiváló kapcsolatépítési képességre. Teljesítménybefolyásoló tényezőnek számítanak a gyakorlati kompetenciák is, mint például a szakértelem és a tapasztalat kombinációja, de $a$ legkönnyebben az érzelmileg kompetens dolgozók tudnak alkalmazkodni a változásokhoz.

Az érzelmi intelligencia szintje meghatározza, hogy egy ember mennyire képes elsajátítani az érzelmi intelligencia elemeire alapuló gyakorlati készségeket, az érzelmi kompetencia pedig rávilágít, hogy ebből mennyi hasznosul a munkahelyen (Kunos, 2011). 
Goleman (1998) a személyes és szociális kompetenciákat öt fő csoportba sorolta, melyet az 1. ábra szemléltet.

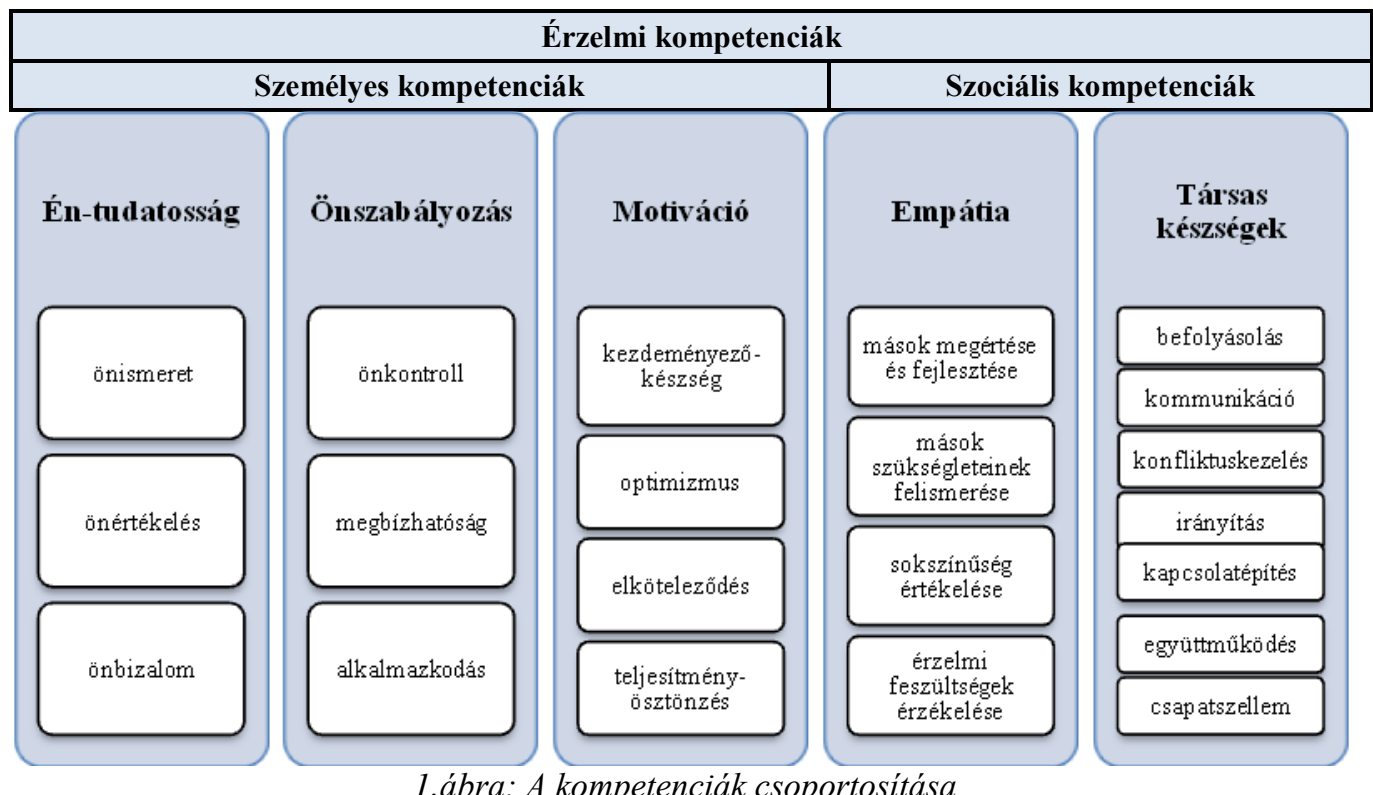

Forrás: Goleman, et al., (2003) és Goleman, (2008) alapján saját szerkesztés

Az érzelmi intelligencia fejlődése - akárcsak az intellektuális tanulás - élethosszig tart. Fejlesztésére az egyének, de a szervezetek is dolgozhatnak ki stratégiákat. A szervezetek általában kétféle stratégiát követnek, vagy a személyes -, vagy a szociális kompetenciák fejlesztését tüzik ki célul. A személyes kompetenciákat jellemzően egyéni foglalkozások, míg a szociális kompetenciákat föként tréningek során lehet fejleszteni (Göndör, 2007). A személyes fejlödés egy coach vagy mentor segítségével is megvalósulhat, azonban önmagunkat is fejleszthetjük (Veresné, et al., 2018).

\section{Coaching}

A szakirodalomban található számos definíció áttekintését követően értelmezésem szerint $a$ coaching nem más, mint egy fejlödést elösegitö folyamat, amely segit önmagunk megismerésében, a személyes elakadások feloldásában, a saját megoldások megtalálásában, a jövőre fókuszálva, ezáltal javitva a teljesitményt és a személyes kapcsolatokat.

A coaching-nak számos célja lehet, mint például a viselkedés olyan irányú megváltoztatása, amely a teljesítmény növeléséhez szükséges, különbözö üzleti problémák kezelése, folyamatos tanulás, személyes illetve szakmai fejlődés. A coaching-folyamat során magasabb szintü önismeretre teszünk szert, elérhetjük a kívánt viselkedésváltozást, teljesítménynövekedést, a szociális kapcsolatok fejlődését, nagyobb mértékü kitartást, a rugalmasság növekedését, nagyobb toleranciát, és érzelmi kontrollt (Kunos, 2018, p. 94).

\section{Coaching a közszférában}

Ma már számos szervezet alkalmazza a coachingot, mert felismerték, hogy segítségével egyszerre tudják motiválni a munkatársakat és fejleszteni a teljesítményüket. A szervezet a munkatársak tanulásán, fejlődésén keresztül növeli a jóllétüket, ezzel eléri az eredményesség és a hatékonyság 
növekedését (Bodó, et al., 2014). Magyarországon is egyre elfogadottabb a coaching, azonban föként a versenyszférában, pedig a közszférában is nagy szükség lenne rá, hisz a változások komoly kihívások elé állítják a közszférában dolgozókat is. A coaching képes hatni a szervezeti kultúra fejlődésére, az értékrend változására, ami hatékonyabb munkavégzést eredményez.

Komócsin Laura és a Business Coach Kft. kutatásai (2010) (2011) (2015) (2018) és előadásai rávilágítanak arra, hogy a coaching szolgáltatást igénybe vevők száma és aránya a közszférában még mindig elenyésző. A coaching szolgáltatást főként vezetők (felsővezetők, középvezetők) veszik igénybe, míg munkatársi szinten, vagyis a szakértők rendkívül kis arányban részesülnek a szolgáltatásból, annak ellenére, hogy a szakemberek hatékonyságának növelése során is eredményes lehet.

A coaching típusai a résztvevői kör (alanyok) alapján a következők lehetnek:

- egyéni coaching: olyan fejlesztési folyamat, amelyben a résztvevő szakember vagy vezető legfontosabb célja az, hogy a szakmai kihívásokra való reagálásban, problémái megoldásában önmaga is a változási folyamat forrásává, aktív alakítóvá váljon;

- team-coaching: olyan fejlesztő folyamat, melynek során a coach szakember egy közös célért egymással szorosan együttdolgozó csapat müködését támogatja. A folyamat célja a csapat müködési hatékonyságának maximalizálása, a csapaton belüli együttmúködés javítása;

- csoportos coaching: olyan fejlesztő folyamat, amely hasonló helyzetben lévő, hasonló problémákkal küzdö, de egymással nem feltétlenül szorosan együttdolgozó munkatársakat támogat;

- $\quad$ szervezeti coaching: egy szervezetben dolgozó munkatársak számára szervezett (belső) támogatás (Heidrich, 2007).

Előfordulhat azonban, hogy valaki nem tud, vagy nem akar külső segítséghez fordulni, az ilyen esetekben lehetőség van a self-coaching alkalmazására.

A self-coaching olyan személyiségfejlesztési eszközökkel támogatott folyamat, melynek során az egyén saját belső változását, növekedését menedzseli. Pozitív irányú magatartásváltozás érhető el a folyamat során - szakmai és magánéleti területen egyaránt -, ennek hatására az egyén az önismeret és öntudatosság magasabb fokára lép, nagyobb hatékonysággal képes kezelni feladatait, problémáit. Az ön-coaching coaching elemekkel dolgozik, azonban az eszköztárat az egyén önállóan, szakember segítsége nélkül is képes használni (Paksi-Petró, 2017). Egy kis tudatossággal bárki segíthet saját magán, tehát a self-coaching az, amikor önmagunk coach-ává válunk.

Az ön-coaching esetében a létszám1 fö, az egyéni coaching-nál 2, csoportos coaching-nál 3-15, míg a szervezeti coaching esetében akár 50 fö feletti is lehet (Kunos, 2018).

\section{Empirikus kutatás: Self-coaching és személyes fejlődés}

Számos coaching folyamatmodell létezik, melyek közül kutatásom során az első magyar coaching folyamatmodellt kívánom alkalmazni, amely külön hangsúlyt fektet a lezárásra és értékelésre, ezáltal úgy vélem, kiválóan alkalmas arra, hogy saját magunk fejlődését nyomon kövessük. A Komócsin Laura és Benedek Nikoletta coachok által alkotott DIADAL modell hat fázisra osztja fel a coaching folyamatot, melyek a következők (Komócsin, 2009):

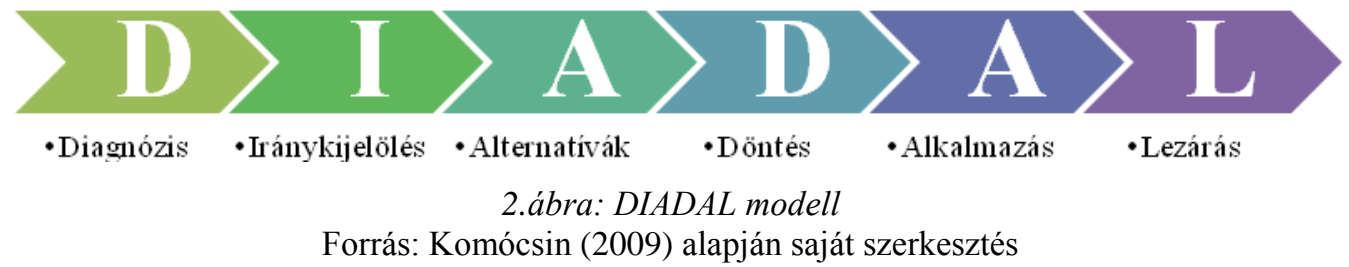


Kutatási kérdésem az volt, hogy a self-coaching alkalmazásával vajon képesek vagyunk-e önállóan a személyes kompetenciáink fejlesztésére. Kifejezetten a közszférára fókuszáltam, hiszen ezen a területen jelenleg elenyésző a coaching szolgáltatást igénybe vevők száma, így átfogó információkkal sem rendelkezünk a témában. Kvalitatív kutatásomban három közszférában dolgozó egyén - egy gyakornok, egy szakértő és egy vezető - vállalkozott arra, hogy tesztek segítségével jobban megismerje magát, saját maga coach-a legyen és fejlessze személyes kompetenciáit, amely által sikeresebb lehet a közszférában. A kutatás 2019 márciusától 2019 szeptemberéig tartott. A self-coaching során főként Komócsin által írt vagy szerkesztett (Komócsin, 2009) (Bán, et al., 2011) könyveket, illetve Kunos (2011) által ajánlott gyakorlatokat használták. Mélyinterjú készítése minden résztvevővel három alkalommal történt, egyéni interjú formájában.

A Diagnózis fázisban a résztvevők felmérték az aktuális helyzetet, meghatározták, honnan indul a coaching folyamat. A diagnózis fázis tesztjeit papír-ceruza formában töltötték ki. A teszteket a fázishoz Komócsin (2009) által ajánlott coaching eszközök közül önállóan választották ki. A kitöltés és az eredmények értékelése közben mindhárom résztvevő mesélt magáról, a kihívásairól.

\section{Szakértő}

Azért választotta a self-coachingot, mert úgy érezte, hogy nem tud megfelelni minden elvárásnak. Munka mellett tanult, de a munka és tanulás mellett nem maradt ideje és energiája másra. Elsőként a Kunos (2011, pp. 45-46) által bemutatott „,Gondolkodási stílus” kérdőívet választotta, amely kérdőív Jung személyiségtípusokról alkotott elméletére épül. A teszt segítségével megtudta, hogy:

- Hova összpontosítja a figyelmét, honnan szerez energiát. (E- extrovertált; I- introvertált)

- Hogyan észlel, szerez információt. (S- érzékelő; N- intuitív)

- Miképp hoz döntéseket, milyen alapon ítéli meg a környezetét. (T-gondolkodás; F- érzés)

- Hogyan viszonyul a külvilághoz. (J - megítélő; P - észlelő) (Kunos, 2011)

Személyiségtípusa szerint INTJ, a munkájára a maximalizmus és erkölcs a jellemző. Független másoktól személyileg és anyagilag egyaránt, mely függetlenség a munkájában is megmutatkozik, ugyanis leginkább egyedül szeret dolgozni. Könnyen beleun a rutinba. Analitikus, gyakran használja a kritikai képességeit, nem érzelgős.

Erősségei a munkája során:

- maximalizmusa miatt nem tudja elviselni, ha hibázik, ezért nagyon precízen hajt végre minden feladatot

- nagyon figyel a részletekre, ezért a legapróbb hibát is észreveszi

- folyamatosan tanul, szereti a változatosságot, ezért külön öröm számára, ha a munkájában is új területen próbálhatja ki és fejlesztheti magát

- nehezen viseli a késést, ezért a feladatait mindig határidőre elkészíti

Az utóbbi időben a munkaidőn túl is dolgozott, akár napi 10 - 11 órát is, és egyre nagyobb teherként nehezedett rá, hogy a munkán és tanuláson kívüli életterülete beszükült. Sportolni hónapok óta nem jutott el, a barátaival egyre ritkábban találkozott és mégse tudta úgy befejezni a feladatait, hogy elégedetten ment volna haza, otthon pedig nem tudott a tanulásra koncentrálni.

Elvégezte a Kunos (2011, pp. 121-122) müvében ismertetett „Munkamániás vagyok$e$ ? 'gyakorlatot, és az eredményei azt igazolták, hogy túlhajtja magát. A Benedek (2011, pp. 120-121) által ismertetett „Idögazdálkodási tesztböl” azt is megtudta, hogy érdemes lenne az időgazdálkodásra fókuszálni, így több ideje maradna önmagára, lehetősége nyílna szabadidős tevékenységeire, feltöltődésre, ami örömet okozhat számára, ettől jobban le tudná küzdeni az elé kerülő akadályokat. 


\section{Gyakornok}

Szintén INTJ típus, ambiciózusnak, kissé zárkózottnak és kíváncsinak tartja magát, a csevegés nagy kihívást jelent számára. Empatikus, szívesen segít bárkinek hála vagy ellenszolgáltatás nélkül is. Szabadságát, függetlenségét úgy érzi képtelen feladni, bármilyen korlátozást érez, menekülni próbál. Munkája során mindig a minőségi munkavégzésre törekszik, ezért nagyon nehezen viseli, ha hibázik. Ilyen esetekben sokszor keríti hatalmában kellemetlen érzés, ezért kitöltötte a „,Munkahelyi szorongás kérdöivet”, melyet Kunos (2011, pp. 119-120) mutatott be.

A kapott eredmény arra utalt, hogy erős szorongást érez a munkájával kapcsolatban. Elmondta, hogy alapvetően a prezentációs feladatok, beszámolók töltik el szorongással, úgy érzi, nem elég magabiztos. Fél attól, hogy mások negatívan ítélik meg. Fenti eredmények után úgy döntött, következőként a szintén Kunos (2011, p. 70) által bemutatott „,Rosenberg kérdöivet” tölti ki, hogy megtudja, milyen is az önértékelése, mivel a stabil pozitív önbecsülés elösegíti a kritikus élethelyzetek megfelelö kezelését. Az önértékelése a normál tartományba esett, azonban az alsó határ közelében, ami azt jelenti, hogy indokolt lenne a fejlesztése.

\section{Vezetö}

Ö is kíváncsi volt a gondolkodási stílusára, ezért ezzel a kérdőívvel kezdte a kitöltést. ESTJ típus, tehát azon kevesek egyike, akik természetes vezetők. A munkatársaitól is ugyanazt a megbízhatóságot és munkamorált várja el, mint saját magától. Elvégezte a Kunos (2011, pp. 40-41) mủvében ismertetett ,, Super-Próbát” mellyel bízott benne, hogy megismeri a munkához kapcsolódó értékorientációját, és kap még egy visszaigazolást arra vonatkozóan, hogy a vezető szerep valóban neki való. Az eredmények alapján személyiségének munkára vonatkozó vezető értékei alapján igénye van a vezetésre, fontos számára a mások által végzett vagy végzendő munka megtervezése, megszervezése. Lényeges számára a független gondolkodás is, és annak megismerése, hogy a dolgok hogyan és miként müködnek. Szereti a jó teljesítményt, látható eredményeket hozó munkát preferál. Ugyanakkor nem fontosak számára a társas kapcsolatok, vagyis az, hogy jól kijöjjön a munkatársaival.

Az Iránykijelölés fázisban mindhárom résztvevő kitüzte a célt, hogy mit is szeretnének elérni.

\section{Szakértő}

A Komócsin (2009, pp. 187-189) által bemutatott „Élet- és mókuskerék” gyakorlatot választotta ebben a fázisban, az életére vonatkozóan rajzolta meg a kört, mivel érezte, hogy az utóbbi időben eléggé a munkára fókuszál. A gyakorlat elvégzését követően láthatóvá vált számára, hogy az egészségét és a kapcsolatait is elhanyagolta. Célja tehát heti negyven óra munka, találkozás a barátaival minden héten, heti hat óra tanulás és négy óra mozgás.

\section{Gyakornok}

Szintén az „Élet- és mókuskerék” gyakorlatot választotta az Iránykijelölés szakaszban, felrajzolta a kört az életére és a munkájára vonatkozóan is, mivel az életkerékben az egyik legnagyobb eltérés a jelen és a kívánt állapot között a munka esetében volt, míg a másik terület, amin dolgoznia kell, az „otthon”. A mókuskerékből világossá vált számára, hogy leginkább azért elégedetlen a munkájával, mert nem érzi a biztonságot és a megbecsülést. Ezzel kapcsolatban feltette magának a kérdéseket, hogy vajon mi lehet az oka ennek, és arra a következtetésre jutott, hogy talán azért nem érzi a megbecsülést, mert ő sem becsüli eléggé magát. Szeretné, ha magabiztosabb lenne a munkahelyén és a magánéletében egyaránt. Régóta szeretne saját lakást vásárolni, 
de eddig nem mert belevágni, mert nem hitt abban, hogy meg tudja tartani a munkáját és tudja fizetni a törlesztő részleteket.

\section{Vezetö}

A kereket a munkájára vonatkozóan rajzolta fel, mivel szeretne sikeres vezető lenni. Ezért végiggondolta, mi szükséges ahhoz, hogy valaki jó vezető lehessen. A legnagyobb hiányosságai a motiválás esetében mutatkoztak, ezért ezt szerette volna fejleszteni. Nagyon fontos számára a teljesítmény és tisztában van vele, hogy az embereket úgy lehet magasabb teljesítményre ösztönözni, hogy közben ők is jobban érzik magukat, nagyobb örömet találnak a munkájukban.

Az Alternatívák szakaszban mindhárman alternatívákat gyüjtöttek arra, hogy milyen módon lehetséges a céljuk elérése.

\section{Szakértö}

A Komócsin (2009, p. 213) könyvében ismertetett „Tanácsadó” gyakorlatot választotta, vagyis elképzelte, hogy találkozik valakivel, akinek ugyanez a problémája (mivel tanácsot adni sokkal könnyebb, mint magunk számára megkeresni). A következő javaslatok fogalmazódtak meg benne:

- Keress másik munkahelyet.

- Hagyd abba a tanulást.

- Ne törekedj tökéletességre.

- Mit csinálsz, mikor nem dolgozol? Írd össze, mivel töltöd a napjaidat és összesítsd egy hétre. Ha nem tetszik az eredmény, írj egy új listát, amiben azt rögzíted, hogy hova szeretnél eljutni.

- Ebédelj a barátaiddal.

- Munkanapokon ne ebédelj étteremben, vigyél magaddal ételt.

- Járj gyalog dolgozni.

- Munkába menet hallgasd azt, amit tanulni szeretnél.

- Munkából hazafelé hívd fel a családodat, vagy egy barátodat.

- Dolgozz home office-ban.

- Meditálj.

- Kelj fel korábban és mozogj minden reggel otthon.

- Mozogj minden este otthon, miközben fö a másnapi ebéded.

- Vegyél bérletet egy drága edzőterembe, a pénzt talán nem hagyod veszni.

\section{Gyakornok}

A „,Tanácsadó” gyakorlat során a következő tanácsokat fogalmazta meg:

- Vedd meg a lakást, ha nem tudod fizetni, add ki albérletbe és költözz vissza édesanyádhoz.

- Vállalj mellékállást, így ha elveszted a munkád, akkor is lesz jövedelmed.

- Képezd magad tovább.

- Tanulj valami teljesen mást, amivel úgy érzed, biztosíthatod az állásod a jelenlegi munkahelyeden.

- Mi a hobbid? Dolgozz olyan területen, abban biztos nagyon jó vagy.

- Növeld az önbizalmad, hidd el magadról, hogy képes vagy rá. 


\section{Vezetö}

Úgy vélte, leginkább a motivációs tesztek alkalmasak arra, hogy egyrészt a saját, másrészt a munkatársai motivációs struktúráját felmérje. Ezért a következő teljesítményértékelés során megkérte munkatársait, hogy töltsék ki a Business Coach Kft. (2012) által közzétett „Hét paraméteres szervezeti motivációs tesztet” és a Chapman (2019) által publikált „Szeretetnyelvtesztet”. A „Hét paraméteres szervezeti motivációs teszt” kitöltésekor először megkérte a munkatársait, hogy a tesztben felsoroltak közül válasszanak, mit tartanának fontos szempontnak, ha most pályáznának meg egy új pozíciót. Természetesen megnyugtatta őket, hogy nem kell új állást keresniük és elmondta a célját. Ezt követően kérte, hogy a megjelölt állításokat értékeljék attól függően, hogy azok mennyire fontosak a számukra, majd pedig értékeljék azt, hogy érzik, mennyire jellemzőek azok a jelen helyzetükben. Ezzel megtudta, hogy a munkatársait az önmegvalósítás, a presztízs, a változatosság, az elmélyülés, az anyagiak, a társas kapcsolatok, illetve a tekintély, a hierarchiában betöltött szerep motiválja-e.

Különösen figyelt azokra az esetekre, ahol az első értékelés magas, a második pedig alacsony volt, hiszen tudta, hogy ezek azok a pontok, ahol a munkatársai motiválhatók, hiszen az adott szempontot rendkívül fontosnak találják, viszont úgy érzik, nem élhetnek vele jelenleg. A „,Szeretetnyelv-teszt" kitöltése által pedig megtudta, hogy a munkatársainak mi a legfontosabb; az elismerő szavak, a minőségi idő, az ajándékozás, a szívességek vagy a fizikai érintés.

A Döntés fázisban kiválasztották, hogy milyen módon szeretnék elérni a céljaikat.

\section{Szakértő}

Az alternatívákhoz a Komócsin (2009, pp. 217-218) által bemutatott „Pró és kontra analízis” segítségével listázta, hogy mik az előnyei, mik a hátrányai, majd a legkevesebb hátránnyal és legtöbb előnnyel járó alternatívát, a Király (2017, p. 730) müvében ismertetett „Időmérleg 'készítését választotta.

\section{Gyakornok}

Az alternatívákhoz a „Pró és kontra analizis idődimenzióval” gyakorlatot végezte el, amelyet Komócsin (2009, pp. 219-220) mutatott be. A gyakorlat elvégzése után úgy döntött, hogy a legfontosabb az önbizalma növelése.

\section{Vezeto}

A motivációs tesztek értékelését követően egy Komócsin (2009, pp. 232-234) által bemutatott „Akciótervet” készített, amelyben összeírta, hogy milyen konkrét lépéseket fog megtenni azért, hogy a célját elérje, tehát jobban tudja motiválni a munkatársait.

Az Alkalmazás fázis mindhármuknak kihívást jelentett, ugyanis ki kellett lépniük a komfortzónájukból. Szerencsére azonban mindhárman motiváltak voltak és szerették volna elérni a kitüzött céljukat.

\section{Szakértö}

Két naplót is vezetett egy héten keresztül, egyikben a tevékenységeit naplózta, tehát alaposan megvizsgálta, mennyi időt tölt az alábbi tevékenységekkel: alvás; munka; tanulás; közlekedés; öltözködés/ tisztálkodás/ testápolás; házimunka; tévénézés/ videók/ játékok/ közösségi portálok; olvasás; vásárlás; barátokkal való időtöltés; sport; telefonálás a családtagjaival; ábrándozás. 
Másrészt összeírta, hogy teltek a napjai a munkahelyén. Az alábbi tevékenységekre fordított időt összegezte: munkavégzés eszköz nélkül (információgyüjtés, iratok rendszerezése); munkavégzés eszközzel (telefonálás, e-mailek kezelése, internethasználat, információgyüjtés, szoftverhasználat, táblázatok kezelése); értekezletek; egyéb munkával kapcsolatos tevékenység (közlekedés irodák között, közlekedés nyomtatóhoz, várakozás nyomtatásra); közvetlen kommunikáció (közvetlen beszélgetés, társalgás, segítségnyújtás munkatársnak); étkezés/ italfogyasztás/ dohányzás (ebédelés, kávé/ tea fogyasztása munkamegszakítással, ebéden kívüli étkezések munkamegszakítással, dohányzás); egyéb fiziológiai szükséglet (kézmosás, mosdóhasználat).

Az összegzést követően megállapította, hogy mind a munkahelyén, mind a szabadidejében sok időt tölt időrabló tevékenységekkel, ezzel szemben keveset alszik.

Ezután készített egy „Időgazdálkodási mátrixot” - melyben Benedek (2011, pp. 123-125) müvére támaszkodott-, azaz meghatározta a prioritásokat, fontosság és sürgősség szerint csoportosította a teendöit. A mátrix elkészítéséhez az alábbi 3.ábra volt segítségére.

\begin{tabular}{|c|c|c|}
\hline & Sürgős & Nem sürgós \\
\hline 营 & $\begin{array}{c}\text { Fontos, sürgős } \\
\text { TÜZOLTÂS } \\
\text { Kritikus helyzetek } \\
\text { Égető problémák } \\
\text { Határidős munkák }\end{array}$ & $\begin{array}{c}\text { Fontos, nem sürgős } \\
\text { IDŐBEFEKTETÉS } \\
\text { Megelőzés } \\
\text { Kapcsolatépítés } \\
\text { Érdemi beszélgetések } \\
\text { Új lehetőségek keresése } \\
\text { Fejlődés, tanulás } \\
\text { Alkotás } \\
\text { Megújulás } \\
\text { Tervezés } \\
\text { Rekreáció }\end{array}$ \\
\hline 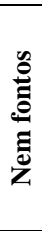 & $\begin{array}{c}\text { Nem fontos, sürgós } \\
\text { APRÓSÁGOK } \\
\text { Váratlan események } \\
\text { Levelezés } \\
\text { Ad hoc megbeszélések } \\
\text { Küszöbön álló ügyek } \\
\text { Népszerü tevékenységek }\end{array}$ & $\begin{array}{c}\text { Nem fontos, nem sürgős } \\
\text { RUTIN } \\
\text { Rutinteendők } \\
\text { Állandó elfoglaltság } \\
\text { Kellemes tevékenységek }\end{array}$ \\
\hline
\end{tabular}

A mátrix elkészítéséhez sok időre volt szüksége, mivel több tevékenységnél is végig kellett gondolnia, hogy az fontos vagy nem fontos; illetve kinek fontos és miért fontos. Az ,Életkerék” mentén megfogalmazott prioritásokat is segítségül hívta. Tudatosan törekedett arra, hogy $a$ „,nem sürgös, de fontos” tevékenységek aránya nöjön, mivel a self-coaching során idáig már megtanulta, hogy ezen tevékenységek elhanyagolása leállitja a fejlödést, az alkotó munkára való képességet. Végiggondolta, mik azok a „sürgős, de nem fontos”, illetve „nem sürgős és nem is fontos” tevékenységek, amelyeket ha nem végez el, időt tud felszabadítani a „fontos, de nem sürgös" feladataira, a barátaira, tanulásra, sportolásra. A mátrix elkészítése több szempontból is hasznosnak bizonyult számára, egyrészt segítségére volt az önfegyelmének erösítésében, másrészt rávilágított azokra a tevékenységekre, amelyek elvették az időt a fontos feladatoktól, amelyekre nemet kell mondani.

Ezt követően a - szintén Benedek (2011, p. 125) által ismertetett - „Tudatos tervezést” alkalmazta, vagyis megkereste azt az időszakot, amelyre el tudta kezdeni beírni az „Életkerék” alapján beazonosított fontos tevékenységeit. Így bekerültek a naptárába azok a tevékenységek, amelyekre eddig nem volt ideje. A gyakorlatok elvégzése közben beazonosította az időrabló tulajdonságait is, vagyis a halogatást és a szétszórtságot. A halogatás kezelésére a Komócsin (2009, p. 236) könyvében bemutatott „Feladatbontást” használta, vagyis listát készített a „nem szeretem” feladatairól, a feladatokat olyan rövid szakaszokra bontotta, amíg egyszerre képes volt fáradtság 
nélkül a témánál maradni. Ha a feladatrészek elvégzése közben eszébe jutott valami, ami nem kapcsolódott az adott témához, azt feljegyezte, és a feladat végeztével tért rá vissza.

A szétszórtsága kezelése már nehezebb volt a munkahelyén. Észrevette, hogy a koncentráltság állapotába is nehezen jut el. A Komócsin (2009, pp. 277-279) müvében ismertetett „eMAP-et”, vagyis az érzelmi térképet hívta segítségül, azaz egy munkanapján keresztül megfigyelte, milyen érzések vannak benne és azok mennyire erösek. Azt is elkezdte figyelni, hogy miképp hatnak az érzelmei a teljesitményére (4. ábra).

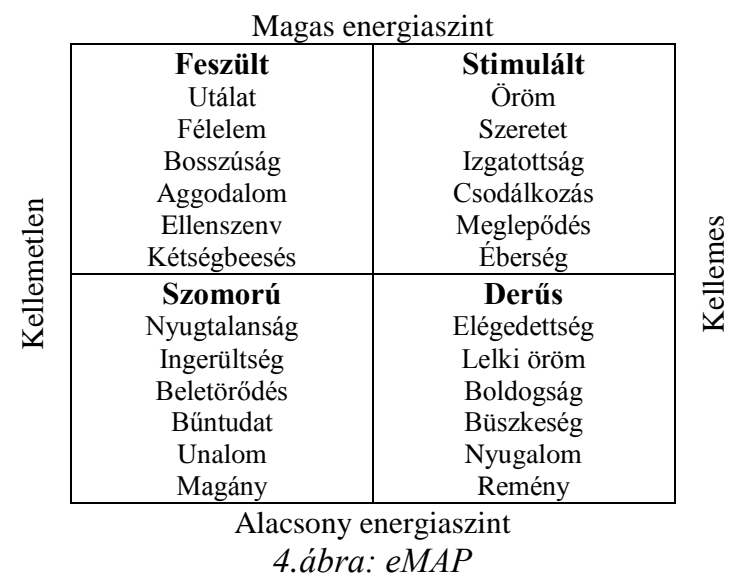

Forrás: Komócsin (2009, p. 278) alapján saját szerkesztés

Tudatosult benne, hogy feszült lesz, ha nem jól halad a munkájával. Mivel egy nagy irodában ült több munkatársával együtt, folyamatosan jöttek-mentek az emberek, csörögtek a telefonok. A helyzetet még nehezítette az is, hogy egy nap többször is meg kellett szakítania munkát, mert valaki segítséget kért tőle, vagy nem a munkához kapcsolódó társalgást kezdeményezett. A munkahelyén nem állt rendelkezésre úgynevezett „,csendes szoba”, ahová elmélyült munka esetén elvonulhatnak az alkalmazottak, a levelezőrendszerét nem kapcsolhatta ki, mivel a napi feladatai egy része e-mailen érkezett, a telefonjának szintén bekapcsolt állapotban kellett lenni, home office-ra nem volt lehetőség. Elsőként a nemet mondás készségét fejlesztette, majd kialakította a rendszert, amivel nagyobb nyugalmat teremthetett magának ahhoz, hogy elmélyülten tudjon dolgozni.A rendszere elemei közé tartozott az, hogy a leveleit nem olvasta azonnal, csak két óránként nyitotta meg a levelező rendszerét, létrehozott egy komolyzenei lejátszási listát, amit fülhallgatóval hallgatva kizárta a zajokat, nyomtatni nem a feladat végeztével ment azonnal, hanem az óránként öt perc pihenőidejében. Kialakított új szokásokat, például hetente többször vitt magával ebédet, így egyrészt kevesebb időre volt szüksége ahhoz, hogy megebédeljen, másrészt ezeken a napokon az informális kommunikációt is az ebédidőre tudta korlátozni. A telefonján az időrabló alkalmazásokhoz napi időkorlátot állított be, és minden nap mozgott - ha csak pár percet is.

\section{Gyakornok}

Az önbizalma növeléséhez először a Kunos - Komócsin (2011, p. 55) szerzőpáros által ismertetett „Érdeklödés” eszközt választotta. Ennek segítségével tíz fötől megkérdezte, hogy milyen pozitív dolgok történtek vele aznap. A hozzá legközelebb álló emberekkel kezdte, a családjával, majd ahogy tapasztalta, hogy ez nem is olyan nehéz feladat, folytatta a barátaival, majd a munkatársai következtek. Azzal, hogy megtapasztalta, hogy mások milyen apró dolgoknak is tudnak örülni, felértékelte a saját sikereit. 
Ezt követöen a „Jó cselekedet” és „,Dicséret” eszközöket alkalmazta, - melyeket szintén Kunos - Komócsin (2011, p. 59) művéből hívott segítségül, - vagyis igyekezett minden nap valami jót tenni valakivel a környezetében. Ez nem okozott nehézséget számára, mivel alapvetően segítőkész ember, a komolyabb feladat számára a dicséret fogadása volt. Hetek teltek el, mire valóban meghallotta a dicséretet, megköszönte és el is hitte. Pozitívum volt számára, hogy egyre több ember ajánlotta fel neki is a segítségét, vagy tett neki valami szívességet.

Majd ezt követően írt egy listát, hogy melyek azok az eredmények, tettek, amire büszke.

Ezután a listáját átalakította a Komócsin $(2009$, p. 253) könyvéből megismert „,Gyözelmi listává”, azaz végiggondolta és le is írta, hogy milyen tulajdonságok és viselkedésformák segítették hozzá a sikerekhez, amelyek a következők voltak: kitartás, szorgalom, logikus gondolkodás, alázat, felelősségvállalás, maximalizmus, megbízhatóság. Ahogy leírta, rájött, hogy ezek a tulajdonságok még mindig jellemzők rá, így a folyamat végére már hitt annyira magában, hogy úgy érezte, bele mer vágni valami új dologba.

Ennek eredményeképp elkezdett lakást keresni, továbbá felmérte, milyen lehetőségei vannak a tanulásra. Az önbizalma erősítése során megismert eszközöket alkalmazta, végül jelentkezett egy képzésre és lefoglalt egy új építésű lakást.

\section{Vezetö}

Nagyon nehéz volt számára ez a fázis, ugyanis a társas kapcsolatok terén hiányosságai voltak. Ezért először a közvetlen környezetén ,gyakorolt”. A családtagjait megkérte, hogy ők is töltsék ki a „,Szeretetnyelv-tesztet” és elöször rajtuk próbálta ki az alkalmazást. Mikor úgy érezte, hogy fejlödött, a barátai következtek. A gyakorlást követően tért csak rá a munkatársai motiválására. Az egyik szakértőjének a szeretetnyelve az ,elismerő szavak”. Ezt az információt úgy használta fel, hogy konkrét helyzetekben megdicsérte a munkatársát.

Egyik esetben például ezt mondta neki: „Tetszett az a segítőkész viselkedés, amit a gyakornokunk irányába tanúsítottál."

Ezzel arra bíztatta öt, hogy máskor is így viselkedjen.

Másik szakértőjének a szeretetnyelve a „minőségi idő”. Mivel az iránykijelölés fázisban kiderült, hogy hiányosságai vannak a figyelmes hallgatás terén, ez nagy kihívás volt számára. Ugyanis most olyan helyzetet kellett teremtenie, amelyben nem ö beszél, hanem hallgat azért, hogy megértse, mi zajlik a munkatársában, milyen problémákkal néz szembe.

Beszélgetésre invitálta tehát a munkatársát az irodájába, a telefonját lenémította és le is fordította, hogy végig tudja tartani a szemkontaktust. Igyekezett a hallottakon kívül a munkatársa érzéseire és testbeszédére is odafigyelni, továbbá próbálta nem félbeszakítani őt.

Egy másik alkalommal pedig, mikor ebédszünetben összetalálkoztak, elment vele ebédelni, mely ebéd során beszélgettek munkáról, szabadidőről, családról.

Lezárás: A self-coaching folyamatot mindhárman azért kezdték el, mert valamin változtatni szerettek volna. Az azonban, hogy megoldást találtak egy problémára, vagy elérték a kitüzött céljukat, még nem jelenti a folyamat végét, ugyanis a változást az életük részévé kell tenniük, új szokásokat kell beépíteniük az életükbe.

\section{Szakértö}

Célja a folyamat kezdetén a következő volt: heti negyven óra munka, találkozás a barátaival minden héten, heti hat óra tanulás és négy óra mozgás, amihez az időgazdálkodásán szeretett volna javítani. A folyamat végén újra elvégezte az „Időgazdálkodás tesztet”, valamint felrajzolta az „Életkereket”, és egyértelmü változást tapasztalt. A célját nem teljesen érte el, mivel nem sikerül minden héten csak negyven órát dolgoznia - de már közelít felé, azonban minden héten találkozik a barátai közül legalább egy emberrel, minden héten fordít legalább hat órát tanulásra, 
új ismeretek megszerzésére, és hetente átlagosan öt órát tölt mozgással. További pozitívumként számolt be arról, hogy a mozgás hatására szebb lett a tartása, csinosabb lett, ami által nőtt az önbizalma.

\section{Gyakornok}

Magabiztosabb szeretett volna lenni a munkahelyén és a magánéletében egyaránt. Szeretett volna saját lakást vásárolni, de nem mert belevágni, mert nem hitt abban, hogy meg tudja tartani a munkáját és tudja fizetni a törlesztő részleteket. A folyamat végére lefoglalta az új építésű lakását és beiratkozott egy egyetemre, ahol olyan végzettséget szerezhet, amellyel kiegészítve a jelenlegit, könnyebben találhat új munkát, ha arra lenne szüksége. A folyamat végén kitöltött teszt és elvégzett gyakorlatok eredményei alapján sokat javult az önértékelése, valamint elégedettebb a munkájával és a magánéletével egyaránt.

\section{Vezetö}

Még nem jutott el eddig fázisig. Alkalmazza új készségeit, és a következő teljesítményértékelést követően szeretné az összegzést elvégezni. Úgy tervezi, hogy végiggondolja az egész folyamatot, megnézi az eredményeket, visszatekint arra, mi segítette és mi hátráltatta.

\section{Következtetések, javaslatok}

A kutatásomban részt vevő, közszférában dolgozó, különböző életkorban, különböző élethelyzetben és különböző pozícióban lévő munkavállalók optimistán álltak a folyamathoz, lelkiismeretesen haladtak lépésről lépésre. A folyamat során nőtt az önismeretünk, a komfortzónájukból való kilépés és a változtatás által az alkalmazkodóképességük, rugalmasságuk, a folyamat véghezvitele pedig növelte az önkontrollt, a kitartást, ezáltal az önbizalmukat is. Úgy gondolom, hogy amely szervezet stratégiájában megjelenik a hatékonyabb és eredményesebb közpénzfelhasználás, szervezetfejlesztés, munkatársak fejlesztése, ott érdemes megfontolni a coaching, mint fejlesztő eszköz alkalmazását. Elképzelhető, hogy mindenki számára nem lesz alkalmas a coaching, ugyanis a folyamatban részt vevőknek motiváltaknak kell lenniük, tehát akarniuk kell a változást, továbbá kitartónak kell lenniük ahhoz, hogy véghezvigyék a folyamatot. Azonban, ha a munkatársak ezen kompetenciáik tekintetében fejlödést érnek el, bármilyen ismeret vagy készség elsajátítása könnyebben megy majd számukra, például sikeresebbek lehetnek az aktuális kihívást jelentő digitalizáció által támasztott elvárásoknak való megfelelésben.

Úgy vélem, a self-coaching alkalmazása a közszférában is megvalósítható. A munkáltató szerepe ebben annyi lehet, hogy lehetőséget biztosít arra, hogy a munkavállalók megismerkedhessenek ezzel a fejlesztési formával. Akár az itt bemutatott DIADAL modell megalkotói, akár más, a self-coachingot ismertetni tudó coach (interaktív) előadása a munkavállalók segítségére lehet.

\section{Irodalomjegyzék}

BÁN Z. ET AL. (2011): Módszertani kézikönyv coachoknak és coachingszemléletű vezetőknek II.. Budapest: Manager Könyvkiadó

BENEDEK N. (2011): Időgazdálkodás. In: L. Komócsin, szerk. Módszertani kézikönyv coachoknak és coachingszemléletủ vezetőknek II.. Budapest: Manager Könyvkiadó, pp. $115-134$.

BODÓ P. ET AL. (2014): Coaching alapok és irányzatok. Budapest: Akadémiai Kiadó

Business Coach Kft. (2012): Lelkesítő munkahely - csak a mesében létezik? Available at: http://www.businesscoach.hu/hirlevel/korlevel1201a/korlevel1201a.htm [Hozzáférés dátuma: 18 szeptember 2019] 
CHAPMAN G. (2019): E-könyv - Az 5 szeretetnyelv: Egymásra hangolva. E-könyv: Harmat

GOLEMAN, D. (1998): What Makes a Leader. Harvard Business Review, November December, pp. 93 - 102.

GOLEMAN, D. (2004): Érzelmi intelligencia a munkahelyen. Budapest: Edge 2000

GOLEMAN, D. (2008): Érzelmi intelligencia. Budapest: Háttér Kiadó

GOLEMAN, D. - BOYATZIS, R. - MCKEE, A. (2003): A természetes vezető. Az érzelmi intelligencia hatalma. Budapest: Vince Kiadó

GÖNDÖR A. (2007): Szervezetfejlesztés: érzelmi intelligencia fejleszési stratégiák. In: P. Majoros, szerk. BGF tudományos évkönyv, 2006: Stratégiák 2007 és 2013 között. Budapest: BGF, pp. 106-113.

HEIDRICH É. (2007): A vezető magányossága, avagy a coaching mint személyre szabott vezetőfejlesztési módszer vezetéselméleti megközelítésben. Vezetéstudomány Budapest Management Review, 38. kötet, pp. 12-27.

KENWORTHY, J. (2008): Competence and competency. What are they anf how do they affect performance?.

Available at: https://issuu.com/johnkenworthy/docs/competence_and_competency [Hozzáférés dátuma: 27 január 2019]

KIRÁLY G. (2017): Időgazdálkodás. In: M. Bábosik, szerk. Vezetés a közjó szolgálatában. Budapest: Typotex, pp. 717-745.

KOMÓCSIN L. (2009): Módszertani kézikönyv coachoknak és coaching szemléletű vezetőknek I.. Budapest: Manager Könyvkiadó

KOMÓCSIN L. (2010): Magyarországi Coaching Kutatás, 2010- Összefoglalás. Humánpolitikai szemle, október. kötet, pp. 3-9.

KOMÓCSIN L. (2011): A coaching helyzete Magyarországon 2011-ben. Humánpolitikai szemle, március. kötet, pp. 21-27.

KOMÓCSIN L. (2015): A 2014.évi coaching kutatás eredményei

Available at: http://coachszemle.hu/rovatok/kutatas/639-a-2014-evi-coaching-kutataseredmenyei.html [Hozzáférés dátuma: 29 augusztus 2019].

KOMÓCSIN L. (2018): A 2018-as országos coaching kutatás eredményei.

Available at: http://www.coachfederation.hu/esemenyek/icf-coach-konferenciasokszinuseg/20180515 [Hozzáférés dátuma: 29 augusztus 2019].

KUNOS I. (2011): Személyiségfejlesztés. Miskolc: Miskolci Egyetemi Kiadó

KUNOS I. (2018): Coaching a társadalom és a gazdaság szolgálatában. Észak-magyarországi Stratégiai Füzetek, 1. kötet, pp. 92-97.

KUNOS I. - KOMÓCSIN L. (2011): Önbizalom-növelés. In: L. Komócsin, szerk. Módszertani kézikönyv coachoknak és coachingszemléletü vezetőknek II.. Budapest: Manager Könyvkiadó, pp. 45-63.

LANGER K. (2001): Karriertervezés. Budapest: Telosz Kiadó

PAKSI-PETRÓ C. (2017): Új és korszerü módszerek a közigazgatási vezetők képzésében. Polgári Szemle, 13. évf. 1-3 szám(DOI: 10.24307/psz.2017.0919), pp. 218-231.

VARGA E. - BODA H. - SZIRA Z. (2017):Gazdálkodj okosan (a kompetenciákkal)! Kompetens munkáltatók és leendő munkavállalók felmérése. In: C. Ágnes, szerk. Vállalkozásfejlesztés a XXI. században VII. tanulmánykötet. Budapest: Óbudai Egyetem, pp. 701-724.

VERESNÉ S. M. - KUCSMA D. - HEGEDÜS M. (2018): Szervezeti és vezetési ismeretek. Budapest: Magyar Könyvvizsgálói Kamara Oktatási Központ 